\title{
Peran Badan Usaha Milik Desa (Bumdes) Dalam Pemberdayaan Ekonomi Masyarakat Di Desa Mas-Mas Kecamatan Batukliang Utara Kabupaten Lombok Tengah
}

\author{
Muhammad Zainul Majdi ${ }^{1}$, Susilawati ${ }^{2}$, Farhana Muhammad ${ }^{3}$, \\ Nurhastuti $^{4}$ \\ ${ }^{1234}$ Prodi Pendidikan Ekonomi FISE Universitas Hamzanwadi \\ email: m.zainulmajdi@gmail.com
}

Received: 29 Nopember, 2020; Accepted: 08 Desember 2020; Published: 17 Desember, 2020

\begin{abstract}
Abstrak
Penelitian ini bertujuan untuk mengetahui peran Badan Usaha Milik Desa (BUMDES) dalam pemberdayaan ekonomi masyarakat di Desa Mas-mas Kecamatan Batukliang Utara Kabupaten Lombok Tengah. Penelitian ini menggunakan pendekatan kualitatif deskriptif. Penelitian dilaksanakan pada bulan juni sampai dengan bulan juli di Desa Mas-mas, Batukliang Utara, Lombok Tengah.Teknik pengumpulan data menggunakan wawancara, dokumentasi, dan observasi dengan subyek penelitian yaitu Kepala Desa, Pengurus BUMDES, dan beberapa masyarakat Desa Mas-mas. Peneliti menggunakan teknik triangulasi sumber. Analisis data dalam penelitian ini menggunakan model analisis interaktif yaitu analisis dengan menggunakan reduksi data, penyajian data, dan verifikasi dan kesimpulan. Hasil penelitian ini menunjukkan bahwa peran BUMDES Lintang Mas belum maksimal dalam pemberdayaan ekonomi masyarakat di desa mas-mas dilihat dari jenis usaha yang dijalankan oleh BUMDES. Selain itu tingkat partisipasi masyarakat yang masih rendah.
\end{abstract}

Kata kunci : Peran; BUMDes; Pemberdayaan Ekonomi Masyarakat

\begin{abstract}
This study aims to know the role of Village-Owned Enterprises (BUMDES) in society economic empowerment at Mas-mas Village, Batukliang Utara District, and Central Lombok Regency. This study was descriptive qualitative approach. The study was conducted from June to July at Mas-Mas Village, Batukliang Utara, and Central Lombok. The data collection techniques used interview, documentation, and observation with study subjects, namely the Head of Village, BUMDES management and some society of Mas-mas. The researcher used techniques of source triangulation. Data analysis in this study uses an interactive analysis model that is analysis using data reduction, data presentation, and verification and conclusions. The results of this study indicated that the role of BUMDES Lintang Mas had not been maximized in society economic empowerment at society of Mas-mas Village; it can be seen from the types of businesses run by BUMDES. In addition, the level of society participation was still low.
\end{abstract}

Keywords: Role; BUMDES; Society Economic Empowerment 


\section{PENDAHULUAN}

BUMDes yang merupakan pilar kegiatan ekonomi di desa yang berfungsi sebagai lembaga sosial (social institution) dan komersial (commercial institution).BUMDes sebagai lembaga sosial berpihak kepada kepentingan masyarakat melalui kontribusinya dalam penyediaan pelayanan sosial.Sedangkan sebagai lembaga komersial bertujuan mencari keuntungan melalui penawaran sumberdaya local (barang dan jasa) ke pasar.Dalam menjalankan usahanya prinsip efisiensi dan efektifitas harus selalu ditekankan.BUMDes sebagai badan hukum, dibentuk berdasarkan tata perundang-undangan yang berlaku, dan sesuai dengan kesepakatan yang terbangun di masyarakat desa.

Dengan demikian, bentuk BUMDes dapat beragam di setiap desa di Indonesia.Ragam bentuk ini sesuai dengan karakteristik lokal, potensi, dan sumber daya yang dimiliki masing-masing desa.Pengaturan lebih lanjut tentang BUMDes diatur melalui Peraturan Daerah (Perda).Selanjutnya tugas dan peran pemerintah adalah melakukan sosialisasi dan penyadaran kepada masyarakat desa melalui pemerintah provinsi dan/atau pemerintah kabupaten tentang arti penting BUMDes bagi kesejahteraan masyarakat.Melalui pemerintah desa masyarakat dimotivasi, disadarkan dan dipersiapkan untuk membangun kehidupannya sendiri.Pemerintah memfasilitasi dalam bentuk pendidikan dan pelatihan dan pemenuhan lainnya yang dapat memperlancar pendirian BUMDes.

BUMDes ini diharapkan juga mampu menstimulasi dan menggerakkan roda perekonomian di pedesaan. Aset ekonomi yang ada di desa harus dikelola sepenuhnya oleh masyarakat desa. Substansi dan filosofi BUMDes harus dijiwai dengan semangat kebersamaan dan self help sebagai upaya memperkuat aspek ekonomi kelembagaan- nya.(Berlian Ramadana and Ribawanto 2013)

Satu hal yang penting dalam pengelolaan BUMDES yakni dalam proses pengelolaan BUMDES amat dibutuhkan suatu pengelolaan dan pelaporan yang transparan bagi pemerintah dan masyarakat. Artinya dasar pengelolaan harus serba transparan dan terbuku sehingga ada mekanisme chek and balance baik oleh pemerintahan desa maupun masyarakat (Febryani et al. 2019) 
Selanjutnya, mekanisme operasionalisasi diserahkan sepenuhnya kepada masyarakat desa.Untuk itu masyarakat desa perlu dipersiapkan terlebih dahulu agar dapat menerima gagasan baru tentang lembaga ekonomi yang memiliki dua fungsi yakni bersifat sosial dan komersial.Dengan tetap berpegang teguh pada karakteristik desa dan nilai- nilai yang hidup dan dihormati.Maka persiapan yang dipandang paling tepat adalah berpusat pada sosialisasi, pendidikan, dan pelatihan kepada pihak-pihak yang berkepentingan terhadap peningkatan standar hidup masyarakat desa (Pemerintah Desa, BPD, tokoh masyarakat/ketua suku, ketuaketua kelembagaan di pedesaan).

Menurut observasi yang dilakukan pada taggal 25 februari 2019 dengan kepala desa bahwa di desa Mas-mas terdiri dari 11 dusun, dengan jumlah penduduk masyarakat 3.197 orang laki-laki dan 3.308 orang perempuan. Desa Mas-mas atau disebut sebagai desa wisata memiliki potensi yang luar biasa, baik dari sumber daya alam (SDA), dilihat dari lahan pertanian yang subur sehingga membuat sebagian orang terjun sebagai petani.Selain menjadi petani, mata pencaharian yang dominan adalah sebagai peternak.

Di Desa Mas-Mas selain dikelilingi dengah sawah juga terdapat Badan Usaha Milik Desa (BUMDes) yang sesuai hasil musyawarah diberi nama "BUMDes LINTANG MAS" yang bergerak dibidang jasa sewa terop dan kursi,dan usaha meubel. BUMDes LINTANG MAS berdiri pada tanggal 15 Februari 2017.Adapun sumber modal BUMDes Lintang Mas sepenuhnya dari Pemerintah Daerah.Didirikannya BUMDes Lintang Mas ini bertujuan untuk menguatkan pengelolaan keuangan, dan diharapkan dapat mendukung munculnya kembali demokrasi sosial didesa melaui peningkatan kapasitas masyarakat desa tentang pengelolaan BUMDes secara berkelanjutan, dan partisipasi masyarakat desa terhadap BUMDes juga tidak lagi berkurang. Di sisi lain, pemerintah desa juga mampu berpola kreatif dan inovatif dalam mendominasi kegiatan ekonomi desa melalui kepemilikan BUMDes sehingga dapat membangun perekonomian daerah yang dibutuhkan untuk menciptakan lapangan pekerjaan baru, mengasilkan barang dan jasa, meningkatkan perdagangan antar- pemerintah daerah dan 
memberikan layanan yang optimal bagi konsumen, karena BUMDes ini bergerak pada bidang jasa dan dagang.

Berdasarkan observasi yang dilakukan tanggal (20 Maret 2019) dan informasi dari masyarakat desa mas-mas yaitu bapak Sopian, bahwasannya keberadaan BUMDes LINTANG MAS tersebut tidak terlalu berpengaruh dalam pertanian, karena BUMDes tersebut bergerak di bidang jasa sewa terop dan kursi, serta meuble, padahal potensi desa mas-mas adalah sebagai desa wisata dan masyarakat dominan bekerja sebagai petani.BUMDes ini tidak bergerak pada bidang jasa simpan-pinjam, padahal jika BUMDes tersebut bergerak pada jasa simpan pinjam petani bisa meminjam pada BUMDes tersebut.

\section{METODE}

Jenis penelitian yang digunakan adalah kualitatif deskriptif yang bertujuan untuk menggambarkan, meringkaskan berbagai kondisi, berbagai situasi, atau berbagai fenomena realitas social yang ada di masyarakat. Metode penelitian kualitatif adalah metode penelitian yang berlandasan pada filtpositivisme, digunakan untuk meneliti pada kondisi obyek yang alamiah, (sebagai lawannya adalah eksperimen) dimana peneliti adalah sebagai instrument kunci, pengambilan sampel sumber data dilakukan secara purposive dan snowball, teknik pengumpulan dengan trianggulasi (gabungan), analisis data bersifat induktif/kualitatif, dan hasil penelitian kualitatif lebih menekankan makna dari pada generalisasi. (Sugiyono 2008)

Teknik pengambilan sampel sumber data dengan pertimbangan tertentu, pertimbangan tertentu ini, misalnya orang tersebut yang dianggap paling tahu tentang apa yang kita harapkan, atau mungkin dia sebagai penguasa sehingga akan memudahkan peneliti menjelajahi obyek/situasi sosial yang diteliti. Informan pokok menggunakan purposive sampling, sedangkan informan tambahan menggunakan Snowball Sampling, dengan cara observasi, wawancara dan dokumentasi.

Keabsahan data merupakan konsep penting yang diperbaharui dari konsep keshahihan (validitas) dan keandalan (realibilittas) menurut versi positivisme dan disesuaikan dengan tuntunan pengetahuan kriteria dan paradigma sendiri. 
(Moleong 2013). Ada beberapa langkah yang digunakan untuk membuktikan data yang di dapat valid, yaitu: meningkatkan ketekunan, diskusi teman sejawat, dan triangulasi. Dalam penelitian ini, triangulasi yang digunakan adalah triangulasi tehnik, triangulasi metode dan triangulasi sumber (Sugiyono 2007)

Teknik analisis data yang digunakan dalam penelitian ini adalah aktivitas pengumpulan data, data reduction (reduksi data), data display (penyajian data), dan conclusion drawing atau penarikan kesimpulan/verifikasi.

\section{HASIL PENELITIAN DAN PEMBAHASAN}

Paradigma pemberdayaan ekonomi rakyat sebenarnya bukan saja berupa tuntutan atas pembagian secara adil aset ekonomi, tetapi juga merupakan keniscayaan ideologis dengan semangat meruntuhkan dominasi-dominasi birokrasi dalam mengatur dan menentukan kehidupan rakyat (Sasono, 1999). Gagasan pemberdayaan ekonomi rakyat, menurut Mahmudi (1999), merupakan upaya mendorong dan melindungi tumbuh dan berkembangnya kekuatan ekonomi lokal dan penguasaan ilmu pengetahuan dan teknologi yang berbasiskan para kekuatan rakyat. Muatan gagasan ini tidak saja dituntut untuk dapat mendayagunakan dan menghasilgunakan potensi sumberdaya lokal untuk kepentingan kesejahteraan rakyat, tetapi juga terlindungnya hak-hak rakyat dalam pengelolaan sumber daya lokal sesuai dengan kepentingan ekonomi dan sosialnya. Dengan kata lain, sentralisasi ekonomi bertentangan dengan gagasan dasar pemberdayaan ekonomi rakyat. Untuk itu, perlu dipilih pendekatan dan strategi yang tepat.(Devi Deswimar 2014)

BUMDes Lintang Mas didirikan pada tahun 2017, dengan pengelolanya yaitu Bapak Najamuddin, M.Pd sebagai ketua BUMDes, Bapak Jus An sebagai sekertaris BUMDes, dan Bapak Muhammad Zainuddin sebagai bendahara BUMDes.Pada awal berdirinya BUMDes Lintang Mas usaha-usaha yang dijanlakan yaitu jasa simpan pinjam, jasa sewa terop dan kursi, bengkel, dan meuble. Namun, pada saat ini pengelola BUMDes dan pemerintah desa mentiadakan usaha jasa simpan pinjam dikarenakan tidak lancar, dan usaha meuble juga belum maksimal, jadi saat ini BUMDes menjalankan usaha sewa 
terop dan kursi dan usaha bengkel.BUMDes tidak mempunyai anggota jadi pada awal berdirinya BUMDes modal seluruhnya diberikan oleh desa.

Jika kita mengacu pada dokumen BUMDes yang disampaikan oleh pengurus BUMDes bahwa tujuan berdirinya BUMDes salah satunya yaitu:

1. Untuk memfasilitasi masyarakat miskin,

2. Mendorong perekonomian masyarakat desa,

3. Meningkatkan kreativitas dan peluang usaha ekonomi produktif masyarakat desa,

4. Meningkatkan pendapatan dan kesejahteraan masyarakat desa,

5. Meningkatkan pendapatan asli desa.

Usaha simpan pinjam sangat cocok diadakan oleh BUMDes mengingat masyarakat desa mas-mas banyak yang menjadi petani, dengan itu masyarakat bisa meminjam untuk membeli bibit tanaman ataupun dijadikan sebagai modal usaha.

Berbicara mengenai manfaat yang diberikan oleh BUMDes untuk masyarakat desa mas-mas sudah banyak contohnya yaitu memberikan pinjaman terop secara gratis untuk masyarakat yang kurang mampu.

BUMDes dalam pemberdayaan ekonomi menurut wawancara yang dilakukan dengan informan kunci dan informan tambahan bahwa perannya dalam pemerdayaan ekonomi masyarakat belum maksimal, dikatakan demikian karena jika dilihat dari usaha yang di jalankan oleh BUMDes yaitu: 1) pada usaha jasa sewa terop dan kursi ada pegawai tetap yang diminta oleh BUMDes dalam membantu menjalankan usaha tersebut, 2) pada usaha bengkel juga ada masyarakat khusus yang mnjalankan usaha tersebut, jadi tidak semua masyarakat desa mas-mas mempunyai kesempatan untuk ikut dalam usaha terebut.Selebihnya tidak ada pemberdayaan masyarakat yang dilakukan secara khusus oleh BUMDes.

Desa mas-mas dikenal sebagai desa wisata, oleh karena itu BUMDes pada tahun ini sudah merencanakan bahwa pada tahun 2020 akan mengadakan pelatihan tour guide untuk masyarakat desa mas-mas khususnya para pemda dan pemudi, dan akan membuat waterpark di desa mas-mas. 


\section{KESIMPULAN}

Berdasarkan hasil penelitian dilapangan, maka penyimpulan akhir tentang peranan BUMDes Lintang Mas dalam pemberdayaan ekonomi masyarakat secara umum belum maksimal, dilihat dari usaha-usaha yang djalankan oleh BUMDes Lintang Mas diantaranya, usaha jasa sewa terop dan kursi, usaha bengkel, usaha meubel, usaha simpan pinjam belum maksimal untuk mensejahterakan masyarakat ataupun dalam pemberdayaan ekonomi masyarakat. Tetapi pada saat ini usaha simpan pinjam sudah ditiadakan oleh pengurus BUMDes dikarenakan usaha tersebut tidak berjalan lancar. Sedangkan dilihat dari usaha bengkel dan usaha jasa sewa terop masih berjalan lancar, dan peran BUMDes dalam pemberdayaan ekonomi masyarakat sudah ada namun belum maksimal, karena pada jasa usaha sewa terop dan bengkel sudah ada masyarakat desa sebagai pegawai tetap yang membantu BUMDes utuk menjalankan usaha tersebut sehingga tidak ada kesempatan untuk masyarakat yang lain.

\section{DAFTAR RUJUKAN}

Berlian Ramadana, Coristya, And Heru Ribawanto. 2013. Jap) Keberadaan Badan Usaha Milik Desa (Bumdes) Sebagai Penguatan Ekonomi Desa (Studi Di Desa Landungsari, Kecamatan Dau, Kabupaten Malang).

Devi Deswimar, Almasri; 2014. "Peran Program Pemberdayaan Masyarakat Desa Dalam Pembangunan Pedesaan.” Jurnal El-Riyasah.

Febryani, Hillalliatun Et Al. 2019. "Keberadaan Badan Usaha Milik Desa (Bumdes) Sebagai Penguatan Ekonomi Desa Abiantuwung." Jurnal Ilmiah Akuntansi Dan Humanika.

Moleong, Lexy J. 2013. "Metodologi Penelitian Kualitatif (Cetakan Ke-31)." Bandung: Pt. Remaja Rosdakarya.

Sugiyono. 2008. Metode Penelitian Pendidikan:(Pendekatan Kuantitatif, Kualitatif Dan $R \& D$ ). Alfabeta.

Sugiyono, Metode Penelitian Kuantitatif. 2007. "Kualitataif Dan R\&D, Bandung: Alfabeta, 2010." Sugiyono, Metode Penelitian Kuantitatif Kualitatif Dan $R \& D$ Bandung: Alfabeta. 